Correspondence Hiroyuki Imachi imachi@jamstec.go.jp

\section{Methanocella paludicola gen. nov., sp. nov., a methane-producing archaeon, the first isolate of the lineage 'Rice Cluster l', and proposal of the new archaeal order Methanocellales ord. nov.}

\author{
Sanae Sakai, ${ }^{1}$ Hiroyuki Imachi, ${ }^{1,2}$ Satoshi Hanada, ${ }^{3}$ Akiyoshi Ohashi, ${ }^{1,4}$ \\ Hideki Harada ${ }^{1,5}$ and Yoichi Kamagata ${ }^{1,3,6}$
}
${ }^{1}$ Department of Environmental Systems Engineering, Nagaoka University of Technology, Nagaoka, Niigata 940-2188, Japan
${ }^{2}$ Subground Animalcule Retrieval (SUGAR) Program, Extremobiosphere Research Center, Japan Agency for Marine-Earth Science and Technology (JAMSTEC), Yokosuka, Kanagawa 237-0061, Japan
${ }^{3}$ Institute for Biological Resources and Functions, National Institute of Advanced Industrial Science and Technology (AIST), Tsukuba, Ibaraki 305-8566, Japan
${ }^{4}$ Department of Social and Environmental Engineering, Hiroshima University, Hiroshima 739-8527, Japan
${ }^{5}$ Department of Civil and Environmental Engineering, Tohoku University, Sendai 980-8579, Japan
${ }^{6}$ Research Institute of Genome-Based Biofactory, National Institute of Advanced Industrial Science and Technology (AIST), Sapporo, Hokkaido 062-8517, Japan

\begin{abstract}
A novel mesophilic, hydrogenotrophic methanogen, strain $\mathrm{SANAE}^{\top}$, was isolated from an anaerobic, propionate-degrading enrichment culture, which was originally established from rice paddy soil. The cells were non-motile, Gram-negative and rod-shaped (1.8-2.4 $\mu \mathrm{m}$ long by 0.3$0.6 \mu \mathrm{m}$ wide). Growth of strain $\mathrm{SANAE}^{\top}$ was observed at $25-40{ }^{\circ} \mathrm{C}$, with an optimum temperature range for growth of $35-37^{\circ} \mathrm{C}$. The $\mathrm{pH}$ range for growth was $6.5-7.8$, with an optimum at $\mathrm{pH}$ 7.0. The salinity range for growth was $0-1 \mathrm{~g} \mathrm{NaCl} \mathrm{I}^{-1}(0-17 \mathrm{mM})$. The isolate was able to utilize $\mathrm{H}_{2} / \mathrm{CO}_{2}$ and formate for growth and methane production. The $\mathrm{G}+\mathrm{C}$ content of the genomic DNA was 56.6 mol\%. Based on comparative 16S rRNA gene sequence analysis, strain SANAE $^{\top}$ was affiliated with a clone lineage of the Archaea, Rice Cluster I (RC-I), placing it between the orders Methanosarcinales and Methanomicrobiales within the class

'Methanomicrobia'. 16S rRNA gene sequence similarities between strain SANAE' $^{\top}$ and members of Methanosarcinales were in the range 80.0-82.8\%, and those between the strain and members of Methanomicrobiales ranged from 77.5 to $82.4 \%$. In addition to $16 \mathrm{~S}$ rRNA gene analysis, sequence analysis of the mcrA gene (encoding the $\alpha$ subunit of methyl-coenzyme $M$ reductase, a key enzyme in the methane production pathway) also showed that strain $\mathrm{SANAE}^{\top}$ was affiliated with the RC-I lineage. Here, we propose the name Methanocella paludicola gen. nov., sp. nov. for the isolate, the first of the RC-I lineage. The type strain is $\operatorname{SANAE}^{\top}\left(=\mathrm{JCM} 13418^{\top}=\mathrm{NBRC}\right.$ $101707^{\top}=\mathrm{DSM} 17711^{\top}$ ). In addition, we also propose the status of order for the RC-I lineage, for which we propose the name Methanocellales ord. nov.
\end{abstract}

Rice paddy fields are one of the major sources of the greenhouse gas methane, contributing about 10-25\% of global methane emission (Dentener et al., 2001; Neue,

Abbreviation: RC-I, Rice Cluster I.

The GenBank/EMBL/DDBJ accession numbers for the 16S rRNA gene and $m c r A$ gene sequences of strain SANAE $^{\top}$ are $A B 196288$ and AB300467, respectively.
1993). Methane emission from rice paddy fields is attributed to methanogenic Archaea (methanogens), the key organisms responsible for the final step of the anoxic degradation of organic substances. The Rice Cluster I (RC-I) lineage, which hitherto has been comprised solely of $16 \mathrm{~S}$ rRNA gene clone sequences, plays a key role in methane production in rice paddy fields ( $\mathrm{Lu} \&$ Conrad, 2005; Conrad et al., 2006). Despite their numerical 
significance and cosmopolitan dispersal, RC-I methanogens have so far escaped isolation.

Recently, we have successfully isolated a novel methanogenic archaeon, designated strain $\mathrm{SANAE}^{\mathrm{T}}$, belonging to the RC-I lineage from a Japanese rice paddy field. Enrichment and isolation of strain $\mathrm{SANAE}^{\mathrm{T}}$ was achieved by application of the co-culture approach with Syntrophobacter fumaroxidans as the hydrogen-producing syntrophic partner (Sakai et al., 2007). In a previous publication we described the isolation of strain $\mathrm{SANAE}^{\mathrm{T}}$. Here we give a detailed description of strain $\mathrm{SANAE}^{\mathrm{T}}$, including morphological, physiological and genetic properties. We propose that strain $\mathrm{SANAE}^{\mathrm{T}}$ is the type strain of a novel species within a novel genus with the name Methanocella paludicola gen. nov., sp. nov. In addition, we propose the order Methanocellales ord. nov., with the newly isolated methanogen as a representative of the new order.

The basal medium used in this study was prepared as described previously (Sekiguchi et al., 2000). All cultivations were performed at $37{ }^{\circ} \mathrm{C}$ in $50 \mathrm{ml}$ serum vials containing $20 \mathrm{ml}$ medium ( $\mathrm{pH}$ at $25{ }^{\circ} \mathrm{C}, 7.0$ ) under an atmosphere of $\mathrm{N}_{2} / \mathrm{CO}_{2}(80 / 20, \mathrm{v} / \mathrm{v})$ without shaking, unless otherwise mentioned. Growth and substrate utilization was determined by monitoring the optical density of the cultures (at $600 \mathrm{~nm}$ ) and the concentration of methane. Incubations were stopped after 3 months. The $\mathrm{pH}$, temperature and salinity range of strain $\mathrm{SANAE}^{\mathrm{T}}$ were determined in standard media containing $0.01 \%$ yeast extract and $1 \mathrm{mM}$ acetate. The gas phase contained $\mathrm{H}_{2}$ at approximately $150 \mathrm{kPa}$. Temperature tests were carried out between 18 and $60{ }^{\circ} \mathrm{C}, \mathrm{pH}$ tests between $\mathrm{pH} 5.5$ and 8.0, and salinity tests between 1 and $30 \mathrm{~g} \mathrm{NaCl} \mathrm{l}^{-1}$ (17$513 \mathrm{mM}$ ). During the $\mathrm{pH}$ test, the medium was routinely monitored to observe if the initial $\mathrm{pH}$ conditions were changed or not. Salinity tests were performed using the same medium described above (which already contains $33 \mathrm{mM} \mathrm{Na}^{+}$and $14 \mathrm{mM} \mathrm{Cl}^{-}$). Antibiotics were evaluated with cultures supplemented at final concentrations of $100 \mu \mathrm{g}$ antibiotic $\mathrm{ml}^{-1}$. Antibiotic susceptibility tests were carried out at $37{ }^{\circ} \mathrm{C}$ for a period of 2 months. All measurements were performed in triplicate.

Cell morphology and motility were examined by a phasecontrast microscope (Olympus model BX50F). Gram staining was carried out according to the method of Hucker (Doetsch, 1981). The susceptibility of the isolate to detergents was tested with SDS at concentrations ranging from 0.01 to $2.5 \%$, and cell lysis was determined by microscopic observation of cell integrity. Transmission electron microscopy was performed as described previously (Sekiguchi et al., 2003). Short-chain fatty acids, alcohols, methane, $\mathrm{H}_{2}$ and carbon dioxide were measured as described previously (Imachi et al., 2000, 2002, 2006). The $\mathrm{G}+\mathrm{C}$ content of the genomic DNA was determined by the method of Kamagata \& Mikami (1991).

All procedures for DNA extraction, PCR amplification and sequencing have been reported previously (Imachi et al.,
2006). PCR was carried out using primer pairs Arch21F (DeLong, 1992) and 1490R (Weisburg et al., 1991), and ME1 and ME2 (Hales et al., 1996), for amplification of the 16S rRNA and morA genes, respectively. Phylogenetic analyses were performed using the ARB program (Ludwig et al., 2004). A 16S rRNA gene-based tree was constructed by using the neighbour-joining method (Saitou \& Nei, 1987) for sequences having $>1000 \mathrm{nt}$. Subsequently, shorter sequences were inserted into the tree without changing the tree topology by using the parsimony insertion tool of the ARB program. 16S rRNA gene sequence similarity values were calculated using the Calculate Matrix function of the ARB program with Jukes and Cantor correction (Jukes \& Cantor, 1969; Ludwig et al., 2004). A deduced McrA amino acid sequence-based phylogenetic tree was constructed by the neighbour-joining method implemented in the ARB program with 265 amino acid positions and the percentage acceptance mutations (PAM) distance correction. For both phylogenetic trees, the tree topologies were evaluated by using bootstrap resampling analysis (Felsenstein, 1985) for 1000 replicates with the neighbour-joining, maximumparsimony and maximum-likelihood methods as described previously (Sekiguchi et al., 2006). Fluorescence in situ hybridization was performed as described by Sekiguchi et al. (1998). To detect strain $\mathrm{SANAE}^{\mathrm{T}}$ cells, a $16 \mathrm{~S}$ rRNAtargeted oligonucleotide probe specific for strain $\mathrm{SANAE}^{\mathrm{T}}$, SANAE1136 (Sakai et al., 2007), was used.

Cells of strain SANAE ${ }^{\mathrm{T}}$ were non-motile, rod-shaped, 1.8$2.4 \mu \mathrm{m}$ long and $0.3-0.6 \mu \mathrm{m}$ wide, and occurred singly (Fig. 1). Coccoid cells were observed in a late-exponential phase culture with $\mathrm{H}_{2}$ or formate (Fig. 2). Fluorescence in situ hybridization probe targeting of $\mathrm{SANAE}^{\mathrm{T}}$ cells demonstrated that both cell types belong to strain $\operatorname{SANAE}^{\mathrm{T}}$ (Fig. 2). Cells of strain SANAE ${ }^{\mathrm{T}}$ autofluoresced in epifluorescence microscopy, indicating the presence of the methanogen-specific coenzyme $\mathrm{F}_{420}$. The cells stained

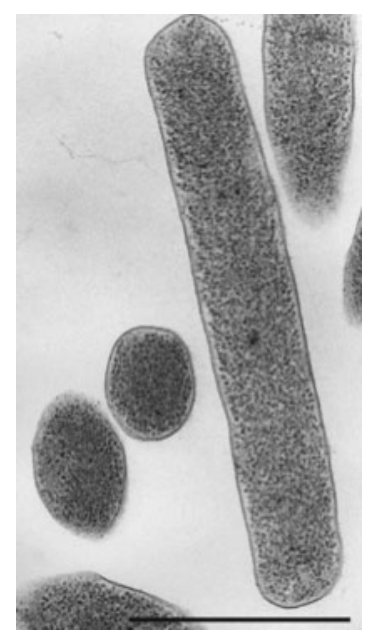

Fig. 1. Transmission electron micrograph of strain $S A N A E^{\top}$. Bar, $1 \mu \mathrm{m}$. 


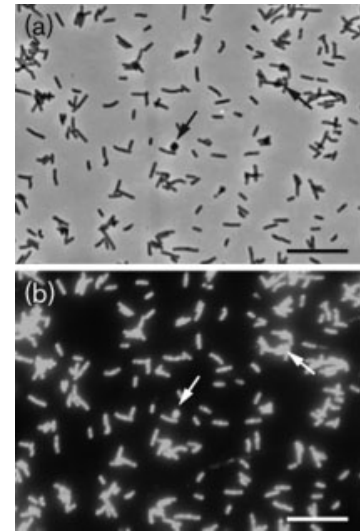

Fig. 2. Photomicrographs of rod and coccoid cells of strain SANAE ${ }^{\top}$. Phase-contrast (a) and fluorescence (b) micrographs of the cells in the same field of view, stained with a Cy-3-labelled $16 \mathrm{~S}$ rRNA probe, SANAE1136. Arrows indicate coccoid cells. Bars, $10 \mu \mathrm{m}$.

Gram-negative and resisted disruption by less than $2 \%$ $(\mathrm{w} / \mathrm{v})$ SDS. Colonies of strain SANAE $^{\mathrm{T}}$ in a deep agar medium were white to cream, reaching a diameter of $1-$ $1.5 \mathrm{~mm}$ after 6 months incubation with $\mathrm{H}_{2}$ as a substrate.

Strain SANAE $^{\mathrm{T}}$ required acetate as carbon source. Yeast extract supported growth; however, it was not required. $\mathrm{H}_{2}$ and formate $(40 \mathrm{mM})$ supported growth and methane production. The following substrates did not support growth and/or methane production: pyruvate $(20 \mathrm{mM})$, lactate $(20 \mathrm{mM})$, acetate $(20 \mathrm{mM}), 1$-propanol $(5 \mathrm{mM})$, 2-propanol (5 mM), ethanol (5 mM), 1-butanol (5 mM), 2-butanol (5 mM), cyclopentanol (5 mM), methanol (20 mM), methylamine $(10 \mathrm{mM})$, trimethylamine $(10 \mathrm{mM})$, dimethylamine $(10 \mathrm{mM})$ and propionate $(20 \mathrm{mM})$.

Strain SANAE $^{\mathrm{T}}$ grew between 25 and $40{ }^{\circ} \mathrm{C}$ with an optimum at $35-37{ }^{\circ} \mathrm{C}$. The $\mathrm{pH}$ range for growth was between 6.5-7.8, with an optimum at around $\mathrm{pH}$ 7.0. The strain could grow at $\mathrm{NaCl}$ concentrations ranging from $0-1 \mathrm{~g} \mathrm{NaCl}^{-1}(0-17 \mathrm{mM})$. In medium containing 2-4 $\mathrm{g} \mathrm{NaCl} \mathrm{l}^{-1}$ (34-68 $\left.\mathrm{mM}\right)$, a small amount of methane was detected; however, growth was inhibited because methane production was not increased. Methane production and growth were completely inhibited by $5 \mathrm{~g} \mathrm{NaCl} \mathrm{l}^{-1}$ $(86 \mathrm{mM})$. Under optimal conditions $\left(\mathrm{pH} \mathrm{7.0,37}{ }^{\circ} \mathrm{C}\right)$, the doubling time, calculated from methane production rates, was 4.2 days. The strain tolerated ampicillin, penicillin $G$, vancomycin, kanamycin, bacitracin and streptomycin. Growth was inhibited by rifampicin, tetracycline and chloramphenicol.

The DNA G + C content of strain SANAE ${ }^{\mathrm{T}}$ was $56.6 \mathrm{~mol} \%$. Analysis of its $16 \mathrm{~S}$ rRNA gene sequence affiliates strain SANAE $^{\mathrm{T}}$ with sequences in the RC-I lineage (previously published in Sakai et al., 2007). Hitherto, this lineage, which falls between the orders Methanosarcinales and
Methanomicrobiales (Fig. 3), was exclusively composed of sequences retrieved from clone libraries. The $16 \mathrm{~S}$ rRNA gene sequence similarities between strain $\mathrm{SANAE}^{\mathrm{T}}$ and members of Methanosarcinales were in the range 80.0$82.8 \%$, and those between the strain and members of Methanomicrobiales ranged from 77.5 to $82.4 \%$. The closest cultured relative of strain $\mathrm{SANAE}^{\mathrm{T}}$ was Methanomethylovorans hollandica ( $82.8 \%$ similarity). In addition to the $16 \mathrm{~S}$ rRNA gene-based analysis, we also determined the partial sequence of the $m c r A$ gene in strain SANAE $^{\mathrm{T}}$ (681 bp) and constructed a phylogenetic tree based on the deduced amino acid sequence of $m c r A$ genes (Fig. 4). In this tree also, strain $\mathrm{SANAE}^{\mathrm{T}}$ affiliates with a member of the RC-I lineage. The closest relative based on McrA amino acid sequence was Methanosalsum zhilinae $(71.8 \%$ similarity).

Phenotypic and genetic analyses in this study showed that strain SANAE $^{\mathrm{T}}$ is an $\mathrm{H}_{2}$-utilizing methanogen and that it should be considered to be a member of the RC-I lineage. Previous culture-dependent and -independent investigations have provided evidence that members of the RC-I lineage utilize $\mathrm{H}_{2}$ (Lueders et al., 2001; Sizova et al., 2003; Erkel et al., 2005, 2006; Lehmann-Richter et al., 1999). Erkel et al. (2006) constructed a complete genome sequence of an RC-I methanogen from an enrichment culture growing on $\mathrm{H}_{2}$ and revealed that the RC-I methanogen had a full set of genes involved in methanogenesis from $\mathrm{H}_{2} / \mathrm{CO}_{2}$. Abundant populations of RC-I Archaea were detected in an acidophilic methanogenic consortium supplemented with $\mathrm{H}_{2}$ as sole energy source (Sizova et al., 2003). The $16 \mathrm{~S}$ rRNA gene sequences from those RC-I enrichments were determined and are available from the Genbank/EMBL/ DDBJ databases as AM114193 for the metagenome (the genome contained three rrn operons) and AF524853 for the acidophilic consortium. The sequence similarities between these RC-I enrichments and strain SANAE ${ }^{\mathrm{T}}$ were in the range 92.2-94.2\%, indicating that strain $\mathrm{SANAE}^{\mathrm{T}}$ and these RC-I organisms are phylogenetically distinct from each other, at least at the species or genus level.

Since the discovery of RC-I, it has been recognized as a different genotypic group from the orders Methanosarcinales and Methanomicrobiales because of the low sequence similarity values with those of the two aforementioned orders (Großkopf et al., 1998). In fact, as described above, the 16S rRNA gene sequence similarities between strain SANAE $^{\mathrm{T}}$ and members of the Methanosarcinales and Methanomicrobiales were also low. Additionally, the bootstrap values of both $16 \mathrm{~S}$ rRNA gene-based and McrA amino acid sequence-based phylogenetic trees solidly supported the three lineages, Methanosarcinales, Methanomicrobiales and RC-I (Figs 3 and 4). These results suggest that RC-I, containing strain $\mathrm{SANAE}^{\mathrm{T}}$, is certainly a monophyletic taxon at order level within the class 'Methanomicrobia' (Garrity et al., 2003). Additionally, the physiological properties of strain SANAE $^{\mathrm{T}}$ distinguish it clearly from members of the order Methanosarcinales, which utilize acetate and simple methylated compounds in contrast to 


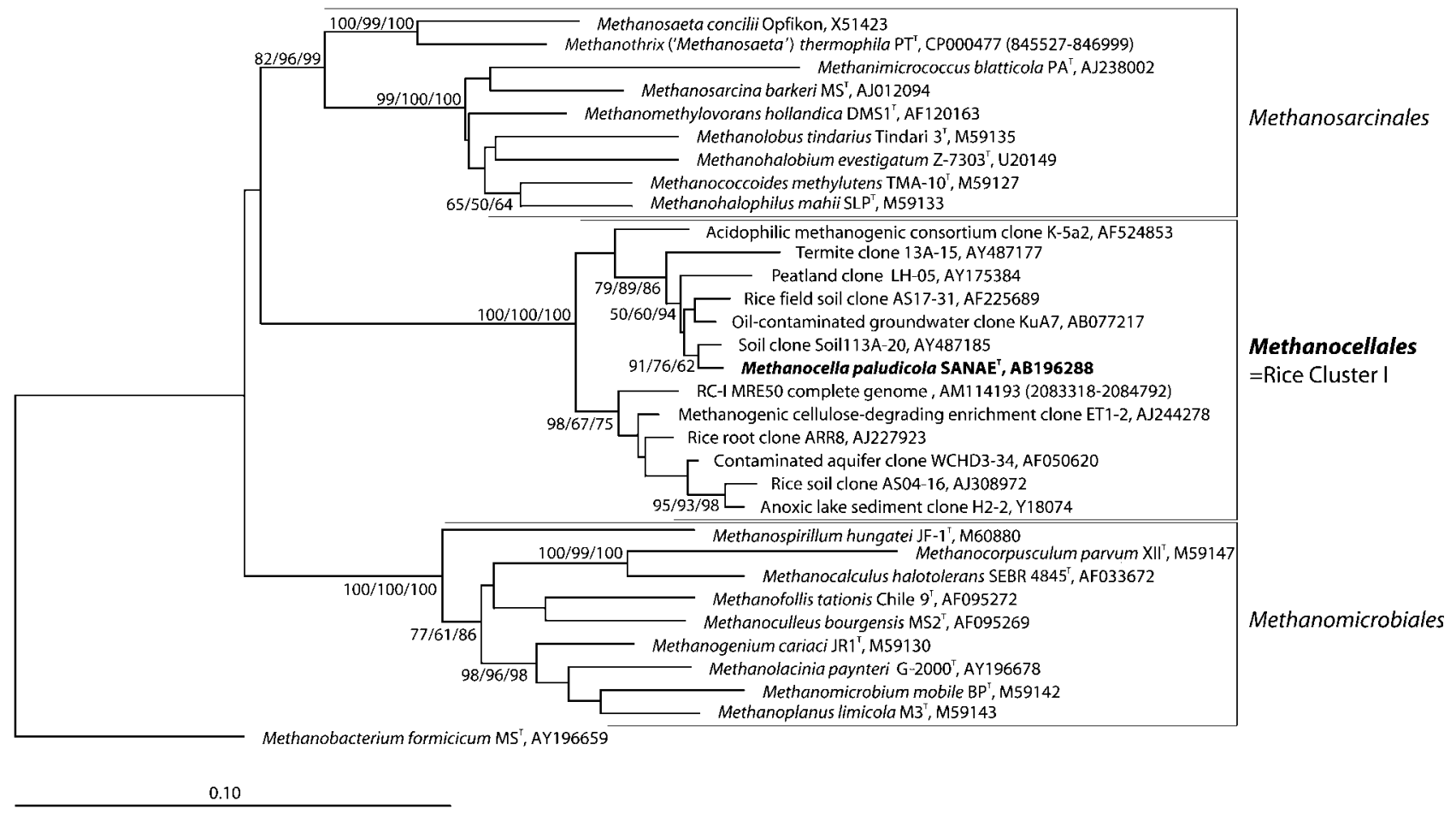

Fig. 3. Phylogenetic tree of the class 'Methanomicrobia' based on comparative analyses of $16 \mathrm{~S}$ rRNA gene sequences, showing the placement of strain SANAE'. The tree was calculated based on a distance matrix analysis of $16 \mathrm{~S}$ rRNA gene sequences (neighbour-joining tree). The 16S rRNA gene sequence of Methanobacterium formicicum (AY196659) was used as the outgroup. The sequences of Methanothrix ('Methanosaeta') thermophila and RC-I MRE50 were inferred from their complete genomic sequences, and the position of each sequence is indicated after their accession number in parentheses. Bootstrap support ( $>50 \%$ indicated only) was obtained from neighbour-joining (first value), maximum-parsimony (second value) and maximum-likelihood methods (third value) based on 1000 replicates. The accession number of each reference sequence is shown after each strain or clone name. The bar represents the number of changes per sequence position.

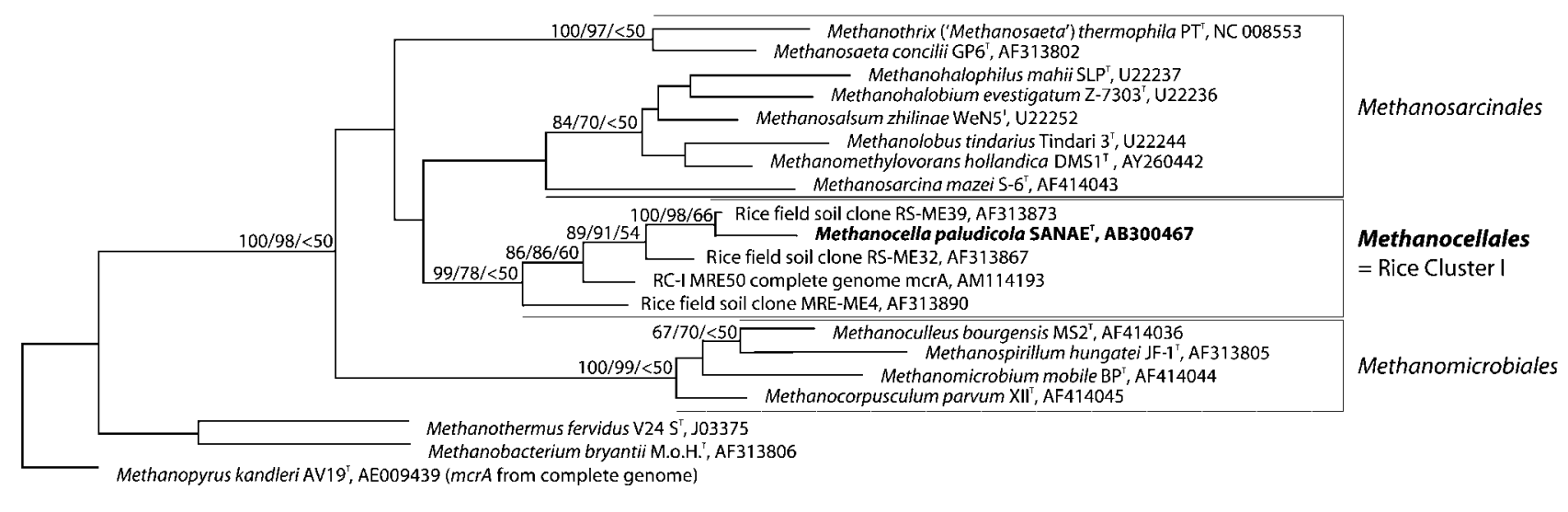

Fig. 4. Phylogenetic tree based on deduced McrA amino acid sequences, indicating the relationship between strain $S A N A E^{\top}$ and related methanogenic Archaea. The tree was constructed based on a distance matrix (265 amino acid positions; PAM distance correction) by using the neighbour-joining method. The sequence of Methanopyrus kandleri (AE009439) was used as the outgroup. Bootstrap support was obtained from neighbour-joining (first value), maximum-parsimony (second value) and maximum-likelihood (third value) methods based on 1000 replicates. The accession number of each reference sequence is shown after each strain or clone name. The bar represents $10 \%$ estimated sequence divergence. 
Table 1. Comparison of morphological and physiological characteristics of strain $\mathrm{SANAE}^{\top}$, and the families and a genus within the orders Methanomicrobiales and Methanosarcinales

Data for strain SANAE ${ }^{\mathrm{T}}$ is from this study. Data for other taxa were taken from the following studies: Methanomicrobiaceae (Boone et al., 1993, 2001a; Chong et al., 2002; Dianou et al., 2001; Mikucki et al., 2003; Lai \& Chen, 2001; Wu et al., 2005); Methanospirillaceae (Boone et al., 2001a); Methanocorpusculaceae (Boone et al., 1993, 2001a); Methanocalculus (Boone et al., 2001a; Lai et al., 2002, 2004; Mori et al., 2000); Methanosaetaceae (Boone et al., 2001b; Ma et al., 2006); Methanosarcinaceae (Boone et al., 1993, 2001b; Jiang et al., 2005; Lomans et al., 1999; Lyimo et al., 2000; Simankova et al., 2001; Singh et al., 2005; Sprenger et al., 2000; von Klein et al., 2002). Abbreviations, -, Negative; +, positive; ; \pm , dependent on the species; ND, not determined.

\begin{tabular}{|c|c|c|c|c|c|c|c|}
\hline \multirow[t]{3}{*}{ Characteristic } & \multirow[t]{3}{*}{ SANAE $^{\mathrm{T}}$} & \multicolumn{4}{|c|}{ Methanomicrobiales } & \multicolumn{2}{|c|}{ Methanosarcinales } \\
\hline & & Methanomicrobiaceae & Methanospirillaceae & Methanocorpusculaceae & Genus & Methanosaetaceae & Methanosarcinaceae \\
\hline & & & & & Methanocalculus & & \\
\hline Cell morphology & $\begin{array}{l}\text { Rod, } \\
\text { coccus* }\end{array}$ & $\begin{array}{l}\text { Curved or irregular rod, } \\
\text { irregular coccus, or } \\
\text { irregular plate or disk }\end{array}$ & Curved rod & Coccus or irregular coccus & Irregular coccus & Rod & $\begin{array}{l}\text { Coccus, irregular } \\
\text { coccus, or flat } \\
\text { polygons }\end{array}$ \\
\hline Gram reaction & - & - & - & - & - & \pm & \pm \\
\hline $\begin{array}{l}\text { DNA G }+C \text { content } \\
(\mathrm{mol} \%)\end{array}$ & 56.6 & $38.7-62.2$ & 45 & $48.5-52$ & $50.8-55$ & $49.0-55.7$ & $36.3-55$ \\
\hline Motility & - & \pm & + (weakly) & \pm & - & - & \pm \\
\hline $\begin{array}{l}\text { Optimum growth } \\
\text { temperature }\left({ }^{\circ} \mathrm{C}\right)\end{array}$ & $35-37$ & $20-55$ & $30-37$ & $30-37$ & $35-38$ & $34-55$ & $20-50$ \\
\hline Optimum pH & 7 & $6.0-7.9$ & $6.6-7.4$ & $6.5-7.0$ & $6.5-7.6$ & $6.7-7.6$ & $6.0-9.5$ \\
\hline \multicolumn{8}{|l|}{ Substrate utilization } \\
\hline $\mathrm{H}_{2} / \mathrm{CO}_{2}$ & + & + & + & + & + & - & \pm \\
\hline Formate & + & + & + & + & + & - & - \\
\hline Acetate & - & - & - & - & - & + & \pm \\
\hline Secondary alcohols & - & \pm & - & \pm & - & - & - \\
\hline Methanol or methylamines & - & - & - & - & - & - & + \\
\hline \multicolumn{8}{|l|}{ Growth requirements } \\
\hline Yeast extract & - & \pm & - & \pm & - & \pm & \pm \\
\hline Acetate & + & \pm & - & \pm & + & ND & ND \\
\hline
\end{tabular}

${ }^{*}$ Cocci are observed in the late-exponential culture. 
strain $\mathrm{SANAE}^{\mathrm{T}}$. However, the phenotypic distinction between strain $\mathrm{SANAE}^{\mathrm{T}}$ and members of the Methanomicrobiales is not so straightforward as both consume hydrogen and formate exclusively and have similar responses to $\mathrm{pH}$, temperature and salinity. They differ, however, in cell shape (Table 1).

Based on these phenotypic and phylogenetic data, we propose that strain SANAE $^{\mathrm{T}}$ is the type strain of a novel species within a novel genus, for which we propose the name Methanocella paludicola gen. nov., sp. nov. We also propose the status of order for the RC-I lineage and propose the name Methanocellales ord. nov.

\section{Description of Methanocella gen. nov.}

Methanocella [Me.tha.no.cel'la. N.Gr. n. methane (from N.Gr. n. meth $(y l)$ and chemical suffix -ane) methane; L. fem. n. cella a room, and in biology a cell; N. L. fem. n. Methanocella a methane-producing cell].

Cells are rod-shaped and non-motile. Gram-negative. Mesophilic. Produces methane from $\mathrm{H}_{2}$ or formate.

The type species is Methanocella paludicola sp. nov.

\section{Description of Methanocella paludicola sp. nov.}

Methanocella paludicola (pa.lu.di'co.la. L. n. palus -udis swamp, muddy environment; L. suff. -cola derived from L. n. incola inhabitant, dweller; N.L. masc. n. paludicola an inhabitant of muddy environments).

Cells occur singly and almost all of the cells are rod-shaped; however, coccoid cells were observed in late-exponential culture. Cells stain Gram-negative, are non-motile and are resistant to lysis by $2 \%(\mathrm{w} / \mathrm{v})$ SDS. Methane produced from $\mathrm{H}_{2}$ and formate. Acetate is required for growth and yeast extract supported growth. Growth occurs between 25 and $40{ }^{\circ} \mathrm{C}$ with the optimum at $35-37{ }^{\circ} \mathrm{C}$. The $\mathrm{pH}$ range is 6.5-7.8; optimum growth occurs at $\mathrm{pH}$ 7.0. Growth was observed in medium containing less than $1 \mathrm{~g} \mathrm{NaCl} \mathrm{l}^{-1}$ $(17 \mathrm{mM})$. The DNA G + C content is $56.6 \mathrm{~mol} \%$.

The type strain, isolated from a rice paddy soil at Nagaoka, Niigata, Japan, is SANAE $^{\mathrm{T}} \quad\left(=\mathrm{JCM} \quad 13418^{\mathrm{T}}=\mathrm{NBRC}\right.$ $101707^{\mathrm{T}}=$ DSM $17711^{\mathrm{T}}$ ).

\section{Description of Methanocellaceae fam. nov.}

Methanocellaceae (Me.tha.no.cel.la'ce.ae N.L. fem. n. Methanocella type genus of the family; -aceae the ending to donate a family; N.L. fem. pl. n. Methanocellaceae the family of the genus Methanocella).

The description is the same as for the genus Methanocella.

The type genus is Methanocella gen. nov.

\section{Description of Methanocellales ord. nov.}

Methanocellales (Me.tha.no.cel.la'les. N.L. fem. n. Methanocella type genus of the order; -ales ending to donate an order; N.L. fem. pl. n. Methanocellales the order of the genus Methanocella).

The order Methanocellales is defined on the basis of a phylogenetic tree constructed by comparative 16S rRNA gene sequence analysis from one isolated strain and a wide variety of environmental clones. The organism uses $\mathrm{H}_{2}$ or formate for growth and methane production.

The type genus is Methanocella gen. nov.

\section{Acknowledgements}

We thank Xian-Ying Meng, Mizuho Muramatsu and Yuji Sekiguchi in National Institute of Advanced Industrial Science and Technology (AIST) for transmission electron microscopy and determination of DNA base content. This research was supported financially by grants from the Japan Society for the Promotion of Science (JSPS), and Institute for Fermentation, Osaka. S. S. was supported by a Research Fellowship of the JSPS for Young Scientists (04663).

\section{References}

Boone, D. R., Whitman, W. B. \& Rouvière, P. (1993). Diversity and taxonomy of methanogens. In Methanogenesis, pp. 35-80. Edited by J. G. Ferry. New York: Chapman \& Hall.

Boone, D. R., Whitman, W. B. \& Koga, Y. (2001a). Order II. Methanomicrobiales. In Bergey's Manual of Systematic Bacteriology, 2nd edn, vol. 1, pp. 246-267. Edited by D. R. Boone \& R. W. Castenholz. New York: Springer.

Boone, D. R., Whitman, W. B. \& Koga, Y. (2001b). Order III. Methanosarcinales. In Bergey's Manual of Systematic Bacteriology, 2nd edn, vol. 1, pp. 248-293. Edited by D. R. Boone \& R. W. Castenholz. New York: Springer.

Chong, S. C., Liu, Y., Cummins, M., Valentine, D. L. \& Boone, D. R. (2002). Methanogenium marinum sp. nov., a $\mathrm{H}_{2}$-using methanogen from Skan Bay, Alaska, and kinetics of $\mathrm{H}_{2}$ utilization. Antonie van Leeuwenhoek 81, 263-270.

Conrad, R., Erkel, C. \& Liesack, W. (2006). Rice Cluster I methanogens, an important group of Archaea producing greenhouse gas in soil. Curr Opin Biotechnol 17, 262-267.

Delong, E. F. (1992). Archaea in coastal marine environments. Proc Natl Acad Sci U S A 89, 5685-5689.

Dentener, F., Derwent, R., Dlugokencky, E., Holland, E., Isaksen, I., Katima, J., Kirchhoff, V., Matson, P., Midgley, P. \& Wang, M. (2001). Climate change 2001, the scientific basis. Third Assessment Report of the Intergovernmental Panel on Climate Change. Cambridge: Cambridge University Press.

Dianou, D., Miyaki, T., Asakawa, S., Morii, H., Nagaoka, K., Oyaizu, H. \& Matsumoto, S. (2001). Methanoculleus chikugoensis sp. nov., a novel methanogenic archaeon isolated from paddy field soil in Japan, and DNA-DNA hybridization among Methanoculleus species. Int J Syst Evol Microbiol 51, 1663-1669.

Doetsch, R. N. (1981). Determinative methods of light microscopy. In Manual of Methods for General Bacteriology, pp. 21-33. Edited by P. Gerhardt, R. G. E. Murray, R. N. Costilow, E. W. Nester, W. A. Wood, N. R. Krieg \& G. H. Phillips. Washington, DC: American Society for Microbiology.

Erkel, C., Kemnitz, D., Kube, M., Ricke, P., Chin, K.-J., Dedysh, S., Reinhardt, R., Conrad, R. \& Liesack, W. (2005). Retrieval of first genome data for rice cluster I methanogens by a combination 
of cultivation and molecular techniques. FEMS Microbiol Ecol 53, 187-204.

Erkel, C., Kube, M., Reinhardt, R. \& Liesack, W. (2006). Genome of Rice Cluster I Archaea - the key methane producers in the rice rhizosphere. Science 313, 370-372.

Felsenstein, J. (1985). Confidence limits on phylogenies: an approach using the bootstrap. Evolution 39, 783-791.

Garrity, G. M., Bell, J. A. \& Lilburn, T. G. (2003). Taxonomic outline of the Procaryotes. In Bergey's Manual of Systematic Bacteriology, 2nd edn, Release 4.0. New York: Springer. doi:10.1007/bergeysoutline 200310

Großkopf, R., Stubner, S. \& Liesack, W. (1998). Novel euryarchaeotal lineages detected on rice roots and in the anoxic bulk soil of flooded rice microcosms. Appl Environ Microbiol 64, 4983-4989.

Hales, B. A., Edwards, C., Ritchie, D. A., Hall, G., Pickup, R. W. \& Saunders, J. R. (1996). Isolation and identification of methanogenspecific DNA from blanket bog peat by PCR amplification and sequence analysis. Appl Environ Microbiol 62, 668-675.

Imachi, H., Sekiguchi, Y., Kamagata, Y., Ohashi, A. \& Harada, H. (2000). Cultivation and in situ detection of a thermophilic bacterium capable of oxidizing propionate in syntrophic association with hydrogenotrophic methanogens in a thermophilic methanogenic granular sludge. Appl Environ Microbiol 66, 3608-3615.

Imachi, H., Sekiguchi, Y., Kamagata, Y., Hanada, S., Ohashi, A. \& Harada, H. (2002). Pelotomaculum thermopropionicum gen. nov., sp. nov., an anaerobic, thermophilic, syntrophic propionate-oxidizing bacterium. Int J Syst Evol Microbiol 52, 1729-1735.

Imachi, H., Sekiguchi, Y., Kamagata, Y., Loy, A., Qiu, Y.-L., Hugenholtz, P., Kimura, N., Wagner, M., Ohashi, A. \& Harada, H. (2006). Non-sulfate-reducing, syntrophic bacteria affiliated with Desulfotomaculum cluster I are widely distributed in methanogenic environments. Appl Environ Microbiol 72, 2080-2091.

Jiang, B., Parshina, S. N., van Doesburg, W., Lomans, B. P. \& Stams, A. J. M. (2005). Methanomethylovorans thermophila sp. nov., a thermophilic, methylotrophic methanogen from an anaerobic reactor fed with methanol. Int J Syst Evol Microbiol 55, 2465-2470.

Jukes, T. H. \& Cantor, C. R. (1969). Evolution of protein molecules. In Mammalian Protein Metabolism, vol. 3, pp. 21-132. Edited by H. N. Munro. New York: Academic Press.

Kamagata, Y. \& Mikami, E. (1991). Isolation and characterization a novel thermophilic Methanosaeta strain. Int J Syst Bacteriol 41, 191-196.

Lai, M.-C. \& Chen, S.-C. (2001). Methanofollis aquaemaris sp. nov., a methanogen isolated from an aquaculture fish pond. Int J Syst Evol Microbiol 51, 1873-1880.

Lai, M.-C., Chen, S.-C., Shu, C.-M., Chiou, M.-S., Wang, C.-C., Chuang, M.-J., Hong, T.-Y., Liu, C.-C., Lai, L.-J. \& Hua, J.-J. (2002). Methanocalculus taiwanensis sp. nov., isolated from an estuarine environment. Int J Syst Evol Microbiol 52, 1799-1806.

Lai, M.-C., Lin, C.-C., Yu, P.-H., Huang, Y.-F. \& Chen, S.-C. (2004). Methanocalculus chunghsingensis sp. nov., isolated from an estuary and a marine fishpond in Taiwan. Int J Syst Evol Microbiol 54, 183-189.

Lehmann-Richter, S., Großkopf, R., Liesack, W., Frenzel, P. \& Conrad, R. (1999). Methanogenic archaea and $\mathrm{CO}_{2}$-dependent methanogenesis on washed rice roots. Environ Microbiol 1, 159-166.

Lomans, B. P., Maas, R., Luderer, R., Op den Camp, H. J., Pol, A., van der Drift, C. \& Vogels, G. D. (1999). Isolation and characterization of Methanomethylovorans hollandica gen. nov., sp. nov., isolated from freshwater sediment, a methylotrophic methanogen able to grow on dimethyl sulfide and methanethiol. Appl Environ Microbiol 65, 3641-3650.
Lu, Y. \& Conrad, R. (2005). In situ stable isotope probing of methanogenic archaea in the rice rhizosphere. Science 309, 1088-1090.

Ludwig, W., Strunk, O., Westram, R., Richter, L., Meier, H., Yadhukumar, Buchner, A., Lai, T., Steppi, S. \& other authors (2004). ARB: a software environment for sequence data. Nucleic Acids Res 32, 1363-1371.

Lueders, T., Chin, K. J., Conrad, R. \& Friedrich, M. (2001). Molecular analyses of methyl-coenzyme $\mathrm{M}$ reductase alpha-subunit $(\mathrm{mcrA})$ genes in rice field soil and enrichment cultures reveal the methanogenic phenotype of a novel archaeal lineage. Environ Microbiol 3, 194-204.

Lyimo, T. J., Pol, A., Op den Camp, H. J. M., Harhangi, H. R. \& Vogels, G. D. (2000). Methanosarcina semesiae sp. nov., a dimethylsulfideutilizing methanogen from mangrove sediment. Int $J$ Syst Evol Microbiol 50, 171-178.

Ma, K., Liu, X. \& Dong, X. (2006). Methanosaeta harundinacea sp. nov., a novel acetate-scavenging methanogen isolated from a UASB reactor. Int J Syst Evol Microbiol 56, 127-131.

Mikucki, J. A., Liu, Y., Delwiche, M., Colwell, F. S. \& Boone, D. R. (2003). Isolation of a methanogen from deep marine sediments that contain methane hydrates, and description of Methanoculleus submarinus sp. nov. Appl Environ Microbiol 69, 3311-3316.

Mori, K., Yamamoto, H., Kamagata, Y., Hatsu, M. \& Takamizawa, K. (2000). Methanocalculus pumilus sp. nov., a heavy-metal-tolerant methanogen isolated from a waste-disposal site. Int J Syst Evol Microbiol 50, 1723-1729.

Neue, H.-U. (1993). Methane emission from rice fields. Bioscience 43, 466-474.

Saitou, N. \& Nei, M. (1987). The neighbor-joining method: a new method for reconstructing phylogenetic trees. Mol Biol Evol 4, 406-425.

Sakai, S., Imachi, H., Sekiguchi, Y., Ohashi, A., Harada, H. \& Kamagata, Y. (2007). Isolation of key methanogens for global methane emission from rice paddy fields: a novel isolate affiliated with the clone cluster Rice Cluster I. Appl Environ Microbiol 73, 4326-4331.

Sekiguchi, Y., Kamagata, Y., Syutsubo, K., Ohashi, A., Harada, H. \& Nakamura, K. (1998). Phylogenetic diversity of mesophilic and thermophilic granular sludges determined by $16 \mathrm{~S}$ rRNA gene analysis. Microbiology 144, 2655-2665.

Sekiguchi, Y., Kamagata, Y., Nakamura, K., Ohashi, A. \& Harada, H. (2000). Syntrophothermus lipocalidus gen. nov., sp. nov., a novel thermophilic, syntrophic, fatty-acid-oxidizing anaerobe which utilizes isobutyrate. Int J Syst Evol Microbiol 50, 771-779.

Sekiguchi, Y., Yamada, T., Hanada, S., Ohashi, A., Harada, H. \& Kamagata, Y. (2003). Anaerolinea thermophila gen. nov., sp. nov. and Caldilinea aerophila gen. nov., sp. nov., novel filamentous thermophiles that represent a previously uncultured lineage of the domain Bacteria at the subphylum level. Int J Syst Evol Microbiol 53, 1843-1851.

Sekiguchi, Y., Imachi, H., Susilorukmi, A., Muramatsu, M., Ohashi, A., Harada, H., Hanada, S. \& Kamagata, Y. (2006). Tepidanaerobacter syntrophicus gen. nov., sp. nov., an anaerobic, moderately thermophilic, syntrophic alcohol- and lactate-degrading bacterium isolated from thermophilic digested sludges. Int J Syst Evol Microbiol 56, 1621-1629.

Simankova, M. V., Parshina, S. N., Tourova, T. P., Kolganova, T. V., Zehnder, A. J. \& Nozhevnikova, A. N. (2001). Methanosarcina lacustris sp. nov., a new psychrotolerant methanogenic archaeon from anoxic lake sediments. Syst Appl Microbiol 24, 362-367.

Singh, N., Kendall, M. M., Liu, Y. \& Boone, D. R. (2005). Isolation and characterization of methylotrophic methanogens from anoxic marine sediments in Skan Bay, Alaska: description of Methanococcoides alaskense sp. nov., and emended description of Methanosarcina baltica. Int J Syst Evol Microbiol 55, 2531-2538. 
Sizova, M. V., Panikov, N. S., Tourova, T. P. \& Flanagan, P. W. (2003). Isolation and characterization of oligotrophic acido-tolerant methanogenic consortia from a Sphagnum peat bog. FEMS Microbiol Ecol 45, 301-315.

Sprenger, W. W., van Belzen, M. C., Rosenberg, J., Hackstein, J. H. P. \& Keltjens, J. T. (2000). Methanomicrococcus blatticola gen. nov., sp. nov., a methanol- and methylamine-reducing methanogen from the hindgut of the cockroach Periplaneta americana. Int J Syst Evol Microbiol 50, 1989-1999. von Klein, D., Arab, H., Völker, H. \& Thomm, M. (2002). Methanosarcina baltica, sp. nov., a novel methanogen isolated from the Gotland Deep of the Baltic Sea. Extremophiles 6, 103-110.

Weisburg, W. G., Barns, S. M., Pelletier, D. A. \& Lane, D. J. (1991). 16S ribosomal DNA amplification for phylogenetic study. J Bacteriol 173, 697-703.

Wu, S.-Y., Chen, S.-C. \& Lai, M.-C. (2005). Methanofollis formosanus sp. nov., isolated from a fish pond. Int J Syst Evol Microbiol 55, 837-842. 